\title{
Serum Thioredoxin (TRX) Levels in Patients With Heart Failure
}

\author{
Chiharu Kishimoto, MD; Keisuke Shioji, MD; Hajime Nakamura, MD*; \\ Yukie Nakayama, BA; Junji Yodoi, MD*; Shigetake Sasayama, MD
}

\begin{abstract}
An increase in oxidative stress is thought to be involved in the progression of heart disease, but the serum level of thioredoxin (TRX), which regulates the cellular redox state, has not been investigated in patients with heart diseases. The present study determined serum TRX levels with a sandwich enzyme-linked immunosorbent assay in a total of 39 patients with dilated cardiomyopathy (DCM) $(n=5)$, acute coronary syndrome (ACS) $(n=7)$ or stable angina $(n=18)$, including effort angina $(n=7)$ and vasospastic angina $(n=11)$, and in control subjects $(n=7)$. The serum TRX level in patients with New York Heart Association (NYHA) functional classes III and IV ( $\mathrm{n}=8$, $33.3 \pm 8.6 \mathrm{ng} / \mathrm{ml})$ was significantly higher than in the control subjects $(\mathrm{n}=7,14.0 \pm 4.6 \mathrm{ng} / \mathrm{ml})$. In addition, the serum TRX levels correlated positively with the severity of NYHA class, and negatively with the left ventricular ejection fraction. The serum TRX levels were elevated in patients with ACS and DCM compared with the controls. These results indicate a possible association between TRX concentration and the severity of heart failure. (Jpn Circ J 2001; 65: 491-494)
\end{abstract}

Key Words: Heart failure; Oxidative stress; Thioredoxin

M any clinical investigations have established that oxidative stress mediated by the generation of reactive oxygen species (ROS) plays an important role in the pathogenesis of coronary artery disease and heart failure!-10 Excessive generation of ROS occurs with myocardial ischemia and reperfusion, and it has been suggested that ROS play a pivotal role in reperfusion injury? ${ }^{2-4}$ In congestive heart failure, myocardial contractility is impaired by either loss of muscle or by pressure or volume overload, which causes myocardial ischemia, resulting in generation of ROS!,9 Heart failure under both acute and chronic conditions is associated with increased oxidative stress, such as superoxide anion and malonyldialdehyde, and reduced antioxidant reserve, such as superoxide dismutase (SOD), catalase and glutathione reductase 5 It has been reported that ROS per se may be involved not only in the genesis, but also in the progression, of heart failure5-10 and that various inhibitors of free radical production and free radical scavengers have protective activities against reperfusion injuries and reperfusion-induced arrhythmias, 3,4 Therefore, the addition of antioxidant drugs may be beneficial in the management of heart failure 5

Adult T-cell leukemia-derived factor (ADF) is identical to thioredoxin (TRX), ${ }^{11,12}$ which is a small multifunctional protein that contains a redox-active disulfide/dithiol within the conserved active site sequence: -Cys-Gly-Pro-Cys ${ }^{3}$ TRX has various important biological activities in both the intra- and extracellular compartments. For example, TRX

(Received October 10, 2000; revised manuscript received February 19, 2001; accepted March 13, 2001)

Department of Cardiovascular Medicine, Graduate School of Medicine and *Department of Biological Responses, Institute for Virus Research, Kyoto University, Kyoto, Japan

Mailing address: Chiharu Kishimoto, MD, PhD, Department of Cardiovascular Medicine, Graduate School of Medicine, Kyoto University, 54 Kawaracho, Shogoin, Sakyo-ku, Kyoto 606-8507, Japan. E-mail: kkishi@kuhp.kyoto-u.ac.jp is stress-inducible, which protects cells from various types of stresses (eg, viral infection, exposure to ultraviolet light, X-ray irradiation) $!^{4,15}$ Moreover, TRX eliminates hydrogen peroxide and acts as a radical scavenger, and recombinant TRX has a protective activity against hydrogen peroxide cytotoxicity, in which the generation of ROS seems to be involved 14,16 TRX suppressed reperfusion-induced arrhythmias in an isolated rat heart model, 4 and overexpression of TRX in transgenic mice was protective for postischemic reperfusion injury in the brain in vivo ${ }^{17}$ However, the levels of TRX that regulate the cellular redox state have not been investigated in human patients with heart diseases. In view of increasing evidence for the involvement of oxidative stress in heart disease, it is interesting to know whether changes in serum TRX levels exist in patients with heart diseases. Therefore, we used an enzyme-linked immunosorbent assay (ELISA) to investigate the clinical significance of serum TRX levels in patients with dilated cardiomyopathy (DCM), acute coronary syndrome (ACS) or stable angina (SA), including effort angina (EA) and vasospastic angina (VSA).

\section{Methods}

\section{Patients and Control Subjects}

Patients and control subjects were all admitted to Kyoto University Hospital between October 1998 and May 2000. The patients were consecutive and their serum samples were available for TRX assay during the study period. The study group comprised 30 patients with DCM $(n=5: 3$ males, 2 females; age, $53.2 \pm 10.5$ years, mean \pm SD), ACS $(\mathrm{n}=7$ : 6 males, 1 female; $64.3 \pm 8.1$ years), or $\mathrm{SA}$ including EA ( $n=7: 5$ males, 2 females; $60.3 \pm 9.1$ years) and VSA $(\mathrm{n}=11: 10$ males, 1 female; $62.8 \pm 9.4$ years), and 7 control subjects ( 4 females, 3 males, $62.1 \pm 9.1$ years; 4 patients with chest pain syndrome, 1 patient with paroxysmal supraventricular tachycardia, 1 patient with paroxysmal atrial flutter, 
Table 1 Clinical Characteristics of the Patients

\begin{tabular}{|c|c|c|c|c|c|}
\hline & \multirow[b]{2}{*}{$\begin{array}{l}D C M \\
(n=5)\end{array}$} & \multirow[b]{2}{*}{$\begin{array}{c}A C S \\
(n=7)\end{array}$} & \multicolumn{2}{|c|}{$S A$} & \multirow[b]{2}{*}{$\begin{array}{c}\text { Control } \\
(n=7)\end{array}$} \\
\hline & & & $\begin{array}{c}E A \\
(n=7)\end{array}$ & $\begin{array}{c}V S A \\
(n=11)\end{array}$ & \\
\hline Age (years) & $53.2 \pm 10.5$ & $64.3 \pm 8.1$ & $60.3 \pm 9.1$ & $62.8 \pm 9.4$ & $62.1 \pm 9.1$ \\
\hline$M / F$ & $3 / 2$ & $6 / 1$ & $5 / 2$ & $10 / 1$ & $4 / 3$ \\
\hline Serum TRX $(\mathrm{ng} / \mathrm{ml})$ & $36.9 \pm 8.6^{*}$ & $30.6 \pm 4.9 *$ & $19.4 \pm 6.3$ & $15.1 \pm 4.7$ & $14.0 \pm 4.6$ \\
\hline NYHA (I/II/III/IV) & $0 / 0 / 4 / 1$ & $3 / 1 / 2 / 0$ & $5 / 2 / 0 / 0$ & $9 / 2 / 0 / 0$ & - \\
\hline
\end{tabular}

${ }^{*} p<0.001$ vs Control. All data are mean $\pm S D$. DCM, dilated cardiomyopathy; ACS, acute coronary syndrome; SA, stable angina; EA, effort angina; VSA, vasospastic angina; TRX, thioredoxin; NYHA, New York Heart Association.

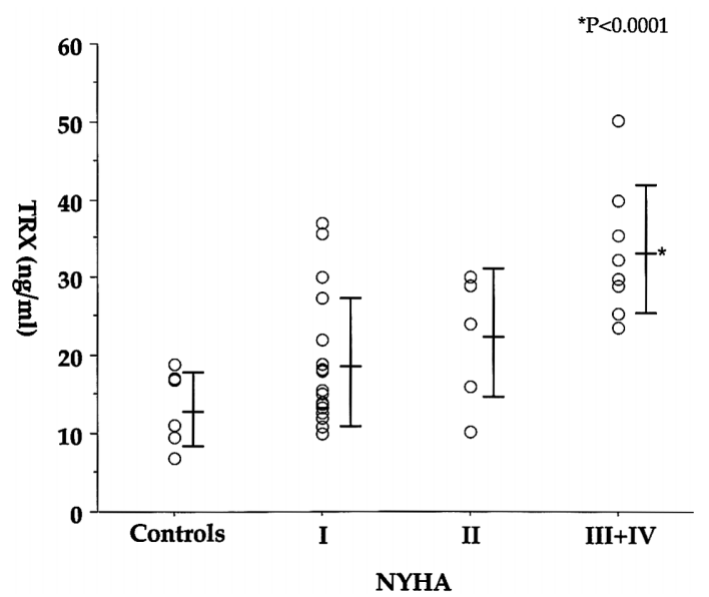

Fig 1. Comparison of the serum TRX levels among patients with NYHA functional class I $(\mathrm{n}=17,19.1 \pm 8.5 \mathrm{ng} / \mathrm{ml})$, II $(\mathrm{n}=5,21.9 \pm 8.5)$, III plus IV ( $\mathrm{n}=8,33.3 \pm 8.6)$, and control subjects $(\mathrm{n}=7,14.0 \pm 4.6)$. Significant differences were found between patients with NYHA III plus IV and control subjects, but not between patients with NYHA I or II and control subjects.

and 1 patient with cerebrovascular accident (CVA)). The study was approved by the Ethics Committee of the Graduate School of Medicine, Kyoto University, and all the patients gave informed consent before entering the study.

The cardiac disability of the patients with heart failure was assessed by New York Heart Association (NYHA) functional class. In all the patients with DCM, coronary angiography and endomyocardial biopsy were performed, and the diagnosis of DCM was made according to standard criteria ${ }^{18}$ Patients with ACS had symptoms of ischemic chest pain at rest within the previous 3 weeks, associated with ECG changes or elevation of creatine kinase-MB isoenzyme. Patients with SA had neither new-onset angina nor accelerated angina during the past month. EA was defined as angina on effort that was associated with transient ST-segment depression, and all these patients underwent coronary angiography and had significant coronary stenosis. VSA was defined as angina at rest that was associated with transient ST-segment elevation or depression, and coronary artery spasm was confirmed by an acetylcholine provocation test $!^{19}$

Serum was obtained from venous blood drawn before breakfast and was stored frozen at $-70^{\circ} \mathrm{C}$ until used.

\section{Enzyme-Linked Immunosorbent Assay}

The serum TRX levels were measured using a sandwich ELISA kit (FujiRebio Co, Ltd) according to the procedure described previously?0 Briefly, in ADF 21-antibody-

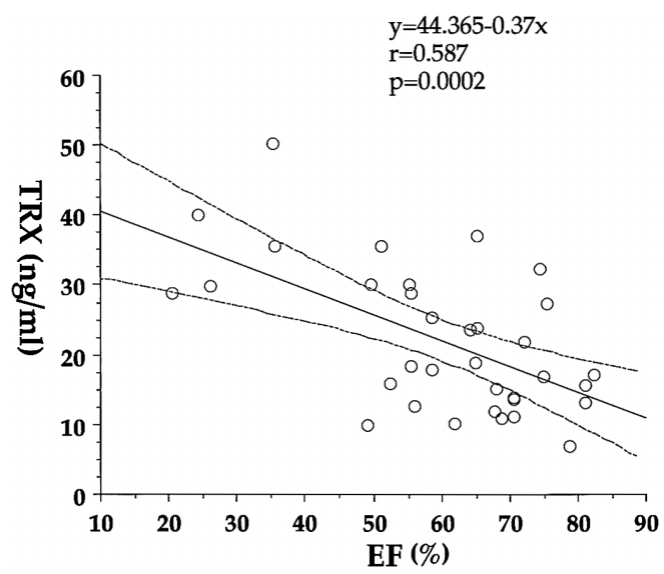

Fig 2. Relation between serum TRX levels and left ventricular ejection fractions (LVEF). The serum TRX levels were inversely correlated with LVEF $(r=0.59, \mathrm{p}=0.0002)$ in all the subjects. Dotted lines indicates $\pm 95 \%$ reliability zone.

precoated 96-microwell plates, $0.2 \mathrm{ml}$ of blocking buffer $(50 \mathrm{~mol} / \mathrm{L}$ phosphate buffer (PBS), $1 \%$ bovine serum albumin, $0.05 \%$ Tween-20, pH 6.0) and $0.02 \mathrm{ml}$ of sample were added to the wells and incubated at room temperature for $2 \mathrm{~h}$. After washing 3 times with PBS containing $0.05 \%$ Tween-20, $0.2 \mathrm{ml}$ of a $75 \mathrm{ng} / \mathrm{ml}$ horseradish peroxidaselabeled anti-ADF 11 antibody was added and incubated at room temperature for $2 \mathrm{~h}$. After washing 5 times with PBS containing $0.05 \%$ Tween-20, $100 \mu 1$ of substrate solution $(1.3 \mathrm{mg} / \mathrm{ml}$ 2,2-azino-di-3-ethyl-benzthiazoline sulfonic acid dissolved in $0.1 \mathrm{~mol} / \mathrm{L}$ triethanolamine-succinate buffer containing $15 \mathrm{mmol} / \mathrm{L}$ hydrogen peroxide, $\mathrm{pH} 4.4$ ) was added and incubated for $1 \mathrm{~h}$ at room temperature. After 0.1 $\mathrm{ml}$ of stopping solution (1\% oxalic acid, $\mathrm{pH} 1.9$ ) was added, the absorption at $405 \mathrm{~nm}(415 \mathrm{~nm})$ was measured with an ELISA reader (Molecular Devices, Menlo Park, CA, USA). Data were analyzed by SOFTmax Version 2.31 (Molecular Devices).

\section{Statistics}

All the values were expressed as mean \pm standard deviation (SD). The error bars in the Figures show the SD of the mean. Statistical analyses were performed on a Macintosh computer (PowerBook G3) using StatView 5.0. The statistical significance of observed difference between patients with heart diseases and control subjects was determined by one-way analysis of variance (ANOVA). Any significant groups detected by ANOVA were reanalyzed with Fisher's protected least significant difference (PLSD) test to characterize significant differences between groups. A value of 
$\mathrm{p}<0.01$ was considered statistically significant. Pearson's rank correlation test was used to assess the relation between ejection fraction $(\mathrm{EF})$ and TRX.

\section{Results}

No statistical significant difference in age among patients with DCM, ACS, EA or VSA, and control subjects was observed. The serum TRX levels did not correlate with age, sex, smoking, total cholesterol concentration, the presence of hypertension, or diabetes. The distribution of NYHA functional class in each group is shown in the Table 1. The serum TRX levels (mean $\pm \mathrm{SD}, \mathrm{ng} / \mathrm{ml}$ ) were significantly higher in patients with DCM $(\mathrm{n}=5,36.9 \pm 8.6)(\mathrm{p}<0.001)$ and ACS $(\mathrm{n}=7,30.6 \pm 4.9) \quad(\mathrm{p}<0.001)$ than in control subjects $(\mathrm{n}=7,14.0 \pm 4.6)$.

We analyzed the association between the severity of NYHA functional class and the serum TRX levels in the control subjects and the patients (Fig 1) and found that the serum level of the patients with NYHA III and IV $(n=8$, $33.3 \pm 8.6)$ was significantly higher than in control subjects $(\mathrm{p}<0.001)$. The serum TRX levels of the patients with NYHA I $(n=17,19.1 \pm 8.5)$ and II $(n=5,21.9 \pm 8.5)$ were higher than in control subjects, but the differences were not significant ( $\mathrm{p}=0.13$ and $\mathrm{p}=0.08$, respectively). In addition, the serum TRX levels inversely correlated with LVEF (Fig 2).

\section{Discussion}

The present study provides the first clinical evidence that serum TRX levels are associated with the NYHA functional class; thatis, the serum TRX levels were elevated in patients with ACS and DCM compared with control subjects, and the levels negatively correlated with EF. The present results indicate a possible association between TRX and the severity of heart failure.

There is a definitive correlation between oxidative stress and ventricular dysfunction, and ventricular remodeling and progressive dilatation leading to end stage heart failure may be mediated by oxygen-derived free radicals 5,10 There is an increase in lipid peroxides in the blood of patients with congestive heart failure, and a significant negative correlation with LVEF6 ROS may exacerbate ischemiainduced injury by promoting unfavorable oxidative changes in membrane lipids and ion pumps, which causes reperfusion-induced arrhythmia. In heart failure, myocardial contractility is impaired by pressure or volume overload, which may cause a relative myocardial ischemia that in turn generates ROS!,9 Moreover, decreased scavenging enzyme activity increases the generation of ROS and the compensatory mechanism of an increase in catecholamines in congestive heart failure also increases ROS ${ }^{20}$ The ROS themselves depress the activity of $\mathrm{Ca}^{2+}$ binding and uptake by the sarcoplasmic reticulum, ${ }^{21}$ which would lead to a decrease in cardiac contractility. The decrease in cellular $\mathrm{pH}$ during ischemia leads to formation of prostaglandins and leukotrienes, and ROS are produced during their synthesis.22 Leukotriene B4 further activates polymorphonuclear leukocytes and increases secretion of neutrophil free radicals . $^{3,24}$ Therefore, it is likely that ROS are involved not only in the pathogenesis, but also in the active progression of congestive heart failure.

TRX is a small, ubiquitous protein with 2 redox-active half-cystein residues in the active center, and it has a cyto- protective effect against oxidation via its redox-active property. 25 TRX has been reported to scavenge hydrogen peroxide directly ${ }^{16}$ and it also regulates the cytotoxic activity of tumor necrosis factor 26 TRX and TRX mRNA are enhanced in the endothelial cells and macrophages of human atherosclerotic plaques, and TRX expression increases in balloon-injured rat arteries ${ }^{27}$ TRX expression is upregulated during the acute stage in rats with giant cell myocarditis, and the development of acute immune-mediated myocarditis may be regulated by the cellular redox state via TRX ${ }^{28}$ Recombinant TRX protected against reperfusion injury in an ischemic lung model ${ }^{29}$ and against reperfusion-induced arrhythmias in an isolated rat heart model, 4 and overexpression of TRX in transgenic mice attenuated focal ischemic brain damage 15 Taken together, these data indicate that TRX protects organs from the cytotoxicity caused by ROS.

Antioxidants, such as SOD and catalase, are reportedly decreased in patients with heart failure, but in the present study, the serum TRX levels in patients with NYHA functional class III or IV, were significantly elevated. We postulate that the increase in the serum concentration of TRX may indirectly reflect the excessive oxidative stress caused by ROS associated with uncontrolled heart failure. Although further studies are necessary, especially on the origin of TRX, it may at present time be concluded that TRX plays a significant pathophysiological role in patients with heart failure.

\section{Acknowledgment}

This work was supported in part by research grants from Japan Cardiovascular Research Foundation and Japanese Education of Science and Welfare (Nos. 08877110 and 09470164).

\section{References}

1. McCord JM: Oxygen-derived fre radicals in postischemic tissue injury. $N$ Engl J Med 1985; 312: 159-163

2. Ferrari R, Alfieri O, Curello S, Ceconi C, Cargnoni A, Marzollo P, et al: Occurrence of oxidative stress during reperfusion of the human heart. Circulation 1990; 81: 201-211

3. Ceconi C, Curello S, Cargnoni A, Ferrari R, Albertini A, Visioli O: The role of glutathione status in the protection against ischaemic and reperfusion damage: Effects of $\mathrm{N}$-acetyl cysteine. J Mol Cell Cardiol 1988; 20: $5-13$

4. Aota M, Matsuda K, Isowa N, Wada H, Yodoi J, Ban T: Protection against reperfusion-induced arrhythmias by human thioredoxin. $J$ Cardiovasc Pharmacol 1996; 27: 727-732

5. Ghatak A, Brar MJ, Agarwal A, Goel N, Rastogi AK, Vaish AK, et al: Oxygen free radical system in heart failure and therapeutic role of oral vitamin E. Int J Cardiol 1996; 57: 119-127

6. Belch JJ, Bridges AB, Scott N, Chopra M: Oxygen free radicals and congestive heart failure. Br Heart J 1991; 65: 245-248

7. Dieterich S, Bieligk U, Beulich K, Hasenfuss G, Prestle J: Gene expression of antioxidative enzymes in the human heart: Increased expression of catalase in the end-stage failing heart. Circulation 2000; 101: $33-39$

8. Chandra M, Chandra N, Agrawal R, Kumar A, Ghatak A, Pandey VC: The free radical system in ischemic heart disease. Int J Cardiol 1994; 43: $121-125$

9. Katz AM: Cellular mechanisms in congestive heart failure. Am J Cardiol 1988; 62: 3A-8A

10. Werns SW, Shea MJ, Lucchesi BR: Free radicals and myocardial injury: Pharmacologic implications. Circulation 1986; 74: 1-5

11. Teshigawara K, Maeda M, Nishino K, Nikaido T, Uchiyama T, Tsudo $\mathrm{M}$, et al: Adult T leukemia cells produce a lymphokine that augments interleukin 2 receptor expression. J Mol Cell Immunol 1985; 2: 17-26

12. Tagaya Y, Maeda Y, Mitsui A, Kondo N, Matsui H, Hamuro J, et al: ATL-derived factor (ADF), an IL-2 receptor/Tac inducer homologous to thioredoxin: Possible involvement of dithiol-reduction in the IL-2 receptor induction. EMBO J 1989; 8: 757-764

13. Holmgren A: Thioredoxin. Annu Rev Biochem 1985; 54: 237-271 
14. Nakamura H, Matsuda M, Furuke K, Kitaoka Y, Iwata S, Toda K, et al: Adult T cell leukemia-derived factor/human thioredoxin protects endothelial F-2 cell injury caused by activated neutrophils or hydrogen peroxide. Immunol Lett 1994; 42: 75-80

15. Nakamura H, Nakamura K, Yodoi J: Redox regulation of cellular activation. Anпи Rev Immunol 1997; 15: 351-369

16. Mitsui A, Hirakawa T, Yodoi J: Reactive oxygen-reducing and protein-refolding activities of adult $\mathrm{T}$ cell leukemia-derived factor/ human thioredoxin. Biochem Biophys Res Commun 1992; 186: 1220 1226

17. Takagi Y, Mitsui A, Nishiyama A, Nozaki K, Sono H, Gon Y, et al: Overexpression of thioredoxin in transgenic mice attenuates focal ischemic brain damage. Proc Natl Acad Sci USA 1999; 96: 41314136

18. Richardson P, McKenna W, Bristow M, Maisch B, Mautner B, O'Connell J, et al: Report of the 1995 World Health Organization/ International Society and Federation of Cardiology. Task force on the definition and classification of cardiomyopathies. Circulation 1996; 93: 841-842

19. Kishimoto C, Lee JD, Shimizu H, Ueda T, Maruya E, Saji H: HLA antigens in patients with variant angina in Japan. Int J Cardiol 1999; 70: $249-252$

20. Graham DG, Tiffany SM, Bell WR Jr, Gutknecht WF: Autoxidation versus covalent binding of quinones as the mechanism of toxicity of dopamine, 6-hydroxydopamine, and related compounds toward C1300 neuroblastoma cells in vitro. Mol Pharmacol 1978; 14: 644653

21. Hess ML, Okabe E, Kontos HA: Proton and free oxygen radical interaction with the calcium transport system of cardiac sarcoplasmic reticulum. J Mol Cell Cardiol 1981; 13: 767-772

22. Dzau VJ, Packer M, Lilly LS, Swartz SL, Hollenberg NK, Williams GH: Prostaglandins in severe congestive heart failure: Relation to activation of the renin-angiotensin system and hyponatremia. $N$ Engl J Med 1984; 310: 347-352

23. Mullane K, Barst S, McGiff JC: Leukotrienes in myocardial ischemia. Prog Clin Biol Res 1985; 199: 127-140

24. Henry TD, Archer SL, Nelson D, Weir EK, From AH: Enhanced chemiluminescence as a measure of oxygen-derived free radical generation during ischemia and reperfusion. Circ Res1990; 67: $1453-1461$

25. Nakamura H, De Rosa S, Roederer M, Anderson MT, Dubs JG, Yodoi J, et al: Elevation of plasma thioredoxin levels in HIV-infected individuals. Int Immunol 1996; 8: 603-611

26. Matsuda M, Masutani H, Nakamura H, Miyajima S, Yamauchi A, Yonehara S, et al: Protective activity of adult T cell leukemia-derived factor (ADF) against tumor necrosis factor-dependent cytotoxicity on U937 cells. J Immunol 1991; 147: 3337-3341

27. Takagi Y, Gon Y, Todaka T, Nozaki K, Nishiyama A, Sono H, et al: Expression of thioredoxin is enhanced in atherosclerotic plaques and during neointima formation in rat arteries. Lab Invest 1998; 78: 957 966

28. Shioji K, Kishimoto C, Nakamura H, Toyokuni S, Nakayama Y, Yodoi J, et al: Upregulation of thioredoxin (TRX) expression in giant cell myocarditis in rats. FEBS Lett 2000; 472: 109-113

29. Yagi K, Liu C, Bando T, Yokomise H, Inui K, Hitomi S, et al: Inhibition of reperfusion injury by human thioredoxin (adult T-cell leukemia-derived factor) in canine lung transplantation. $J$ Thorac Cardiovasc Surg 1994; 108: 913-921 